\title{
特 集
}

||||||||||||||||||||||||||||||||||||||||

\section{粒子ビームサイエンスの進歩と展望一HIMAC の成果を中心に一 \\ 7 章 【放射線安全研究】高エネルギーイオン加速器の放射線安全研究}

\section{2 .6 炭素線治療における放射線防護}

\author{
米内俊祐 ${ }^{\dagger}$ \\ 量子科学技術研究開発機構放射線医学総合研究所物理工学部 \\ 263-8555 千葉県千葉市稲毛区穴川4-9-1 \\ †yonai.shunsuke@qst.go.jp
}

\begin{abstract}
炭素線治療施設の治療運用に倸わる放射線防護のために, HIMAC を用いて行われた実験的研究 について紹介する。これらの研究の結果は, 炭素線治療に扔いて二次中性子等で生じる照射野外 線量は他の放射線治療と同等もしくは低いこと，また，職業被ばく，公衆被ばく，介助者・介護 者の医療被ばくは現行の国内規制基準を十分満足しており，炭素線治療施設における防護が既存 の規制で対応できていることを実証した。
\end{abstract}

Key Words: HIMAC (Heavy Ion Medical Accelerator in Chiba), radio-activation, secondary neutron, occupational exposure, public exposure, medical exposure

\section{1. はじめに}

炭素線治療では高エネルギー荷電粒子を用い るため, それらの荷電粒子が治療に用いる照射 野形成装置や患者と核反応を起こすことにより 高エネルギーの二次中性子が発生する。これら の中性子は治療のターゲット (照射野) から離 れた臟器に対しても低線量の被ばくを与え, さ らには生物学的効果比が高いことから, 治療後 の二次がん発生につながる可能性がある。ま た，上述の核反応や発生した二次中性子により 照射野形成装置や患者が放射化する。照射野形 成装置の放射化物は治療室内で作業を行う医療 従事者やオペレータ, メンテナンスを行うエン ジニアの職業被ばくの線源となり，患者の放射 化は患者家族等の介助者・介護者の被ばくの線 源となりうる。

本稿では炭素線治療に伴う放射線防護におい て特に重要と考え進めてきた1）患者の照射外 線量評価，2）照射野形成装置の放射化による 医療従事者の被ばく線量評価，3）患者の放射
化による介助者・介護者の被ばく線量評価に関 して, HIMAC (Heavy Ion Medical Accelerator in Chiba）を用いた実験的研究を紹介する。

\section{2. 患者の照射野外線量評価}

Fig. 1 にHIMAC 治療室内において, ボナー ボールを用いて測定した中性子エネルギースペ クトルの例を示す ${ }^{1)}$ 。一次炭素線と照射野形成 装置や患者との核反応で発生する二次中性子は $\mathrm{MeV}$ 領域から数百 $\mathrm{MeV}$ のエネルギーが主であ るが, 照射野形成装置内における減速や治療室 の壁, 床, 天井などによる散乱によって，炭素 線治療場に存在する中性子は熱領域から数百 $\mathrm{MeV}$ までの非常に広いエネルギー分布を持つ。 患者の被ばく線量の実験的評価には，これらの エネルギー領域に対応した線量計を用いて，患 者を模擬したファントム内で測定することが必 要であるが, 中性子の寄与のみを測定可能な小 型の線量計は現在のところ利用できない。この ことから, 我々はまず, 熱中性子から高エネル ギー中性子 $(\sim 5 \mathrm{GeV})$ まで感度があるレムカ 
ウンタ：WENDI-II ${ }^{3)}$ を用いた周辺線量当量測 定において, 中性子のみのファントム外線量評 価を行い, 陽子線治療場の測定結果と比較し た。次に, Tissue Equivalent Proportional Counter （TEPC）を用いた水ファントム内吸収線量・線 質測定を行った。後者の測定では，中性子の寄 与に加え, フラグメント等の全放射線種の寄与 が含まれる。

なお，陽子線治療を含む粒子線治療の照射方 法には，拡大ビーム法とスキャニング法が存在 するが，ここでは，特に二次中性子の発生が多 い拡大ビーム法の結果を中心に述べる。

$2 \cdot 1$ 炭素線治療場における中性子周辺線量当 量の測定 ${ }^{4,5}$

\section{$2 \cdot 1 \cdot 1$ 測定方法}

炭素線治療場での測定は, HIMAC 治療室 Bで行った。また, 比較のため, 陽子線治 療施設 3 施設 (筑波大学陽子線治療センター (PMRC), 静岡県立静岡がんセンター (SCC), 国立がんセンター東病院 (NCCHE)) 及び陽 子・炭素線治療施設：兵庫県立粒子線医療セ ンター（HIBMC）の治療室でも測定を行った。 Fig. 2 に, 実験時の写真を示す。生体内から生 成する中性子を模擬するために，アイソセン ターに水ファントムを設置した。測定位置は, 治療ビームに対して $90^{\circ}$ 方向に沿って，アイソ センターとWENDI-II 中心の距離 $d$ で表され る。実験条件は，過去の論文と比較するため に, 照射野: $50 \mathrm{~mm} \times 50 \mathrm{~mm}$, SOBP 幅: $60 \mathrm{~mm}$ を共通照射条件とした。荷電粒子により生成さ れる中性子はエネルギーが高いほど多く生成さ れるため, 各施設の最高エネルギーを用いて, 測定を行った。

\section{$2 \cdot 1 \cdot 2$ 結果}

Fig. 3 に測定結果を放射線医学総合研究所 (以下, 放医研), 新治療研究棟におけるスキャ ンニング法を用いた照射に対する結果とともに 示す。ここで, 各測定值は, SOBP 中心におけ る臨床線量 $[\mathrm{Gy}(\mathrm{RBE})]$ で規格化している。拡

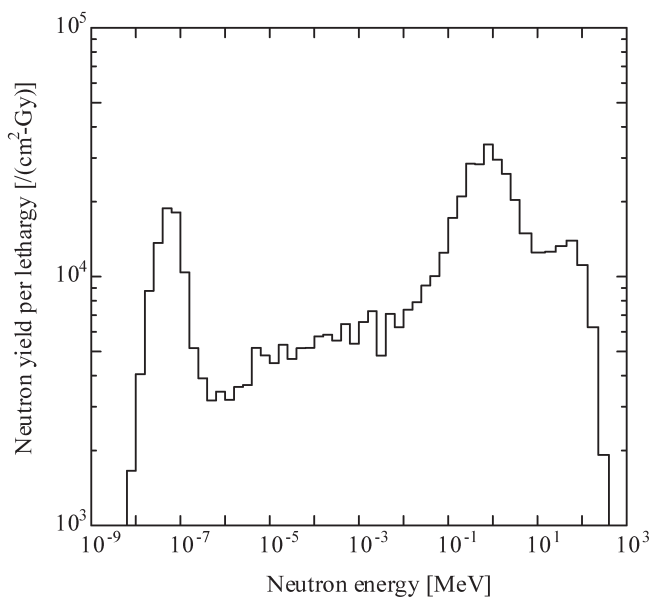

Fig. 1 Measured neutron energy spectrum in the HIMAC treatment room, B by using Boner sphere detectors. ${ }^{1)}$ (The distance from the isocenter and the center of the detector was $173 \mathrm{~cm}$ from along the axis orthogonal to the beam line. The beam condition is as follows: Beam energy: $290 \mathrm{MeV} /$ $\mathrm{u}$, SOBP width: $60 \mathrm{~mm}$, Irradiation field size: $50.0 \mathrm{~mm} \times 58.1 \mathrm{~mm}$. The GRAVEL code ${ }^{2)}$ was used for the unfolding procedure.)

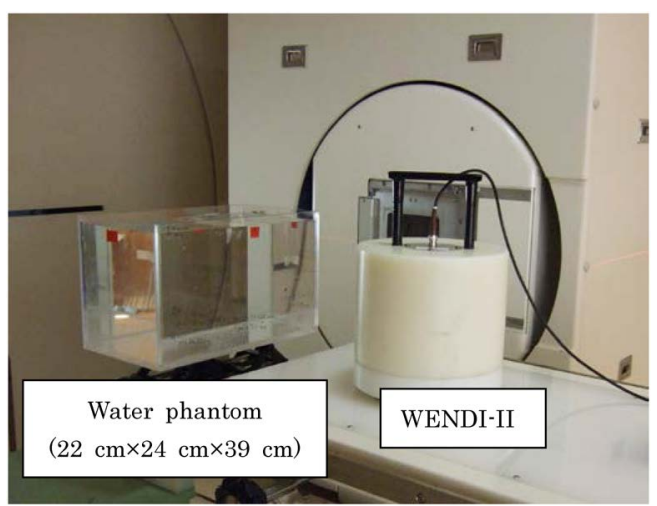

Fig. 2 Photograph of the experimental setup at Shizuoka Cancer Center (Color online).

大ビーム法を用いた HIMAC 治療室の結果は, アイソセンターから $50 \mathrm{~cm}$ の位置で $0.25 \mathrm{mSv} /$ Gy (RBE) で, アイソセンターからの距離とと もに減衰し， $200 \mathrm{~cm}$ の位置では， $0.075 \mathrm{mSv} / \mathrm{Gy}$ （RBE）であった。これらの值は，陽子線治療 場の 4 分の 1 以下である。また, 拡大ビーム法 とスキャニング法の結果を比較した場合，又 キャニング法の中性子周辺線量当量は拡大ビー 
ム法の $10 \%$ 程度であり，二次中性子による患 者の被ばく量を大幅に低減できることが実証さ れた。

\section{$2 \cdot 1 \cdot 3$ 考察及び結論}

本研究以前, 参考文献6）等において, 拡大 ビーム法を用いた粒子線治療は，スキャニング

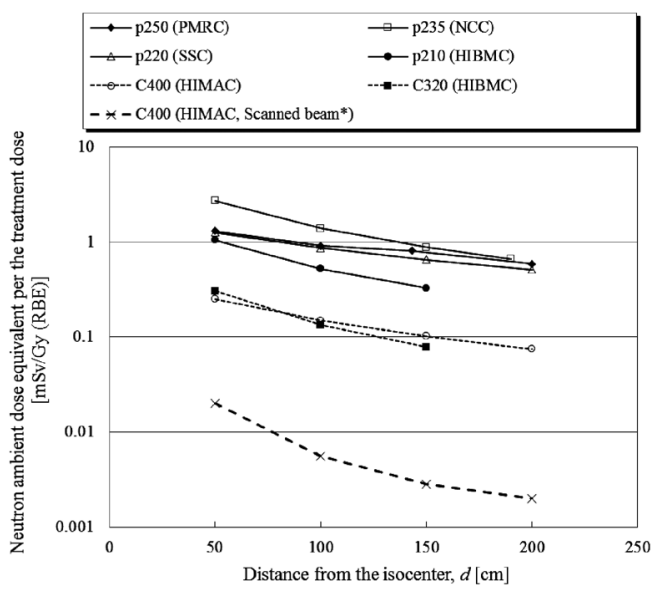

Fig. 3 Measured neutron ambient dose equivaments. ${ }^{3,5)}$ (The legends show the beam species, the energy and facility. "p" and "C" indicate the beam species of proton and carbon, respectively. The following value indicate the beam energy in $\mathrm{MeV} / \mathrm{u}$.)

*: Measured results for scanned beam at the new treatment facility, HIMAC/NIRS. ${ }^{5)}$
ビーム法を用いたものに比べ数百倍の二次中性 子被ばくがあり，治療のベネフィットが二次発 がん等の晚発リスクを下回る可能性があること が指摘されていた。しかしながら，本研究にお ける測定結果は拡大ビーム法を用いた粒子線治 療においても，光中性子を生成する高エネル ギー X 線治療 $(15,18 \mathrm{MV})$ の中性子線量と同等 もしくは，低い值であることを示した。また， 炭素線治療は, 陽子線治療に比へ，処方線量当 たりの中性子線量が低い上，治療当たりの全処 方線量も低いことから，相対的に二次がんリス クの低い粒子線治療であることを示した。一方 で，他の放射線治療モダリティと照射野外線量 及びリスクを比較するためには，さらに照射野 に近い位置での測定が必要である。特に炭素線 治療の場合, 照射野に近い位置では一次炭素線 と生体内の核反応により二次荷電粒子が発生す るため, それらの寄与も含めた照射野外線量評 価が必要である。2.2において，TEPCを用い た照射野外線量測定について述べる。
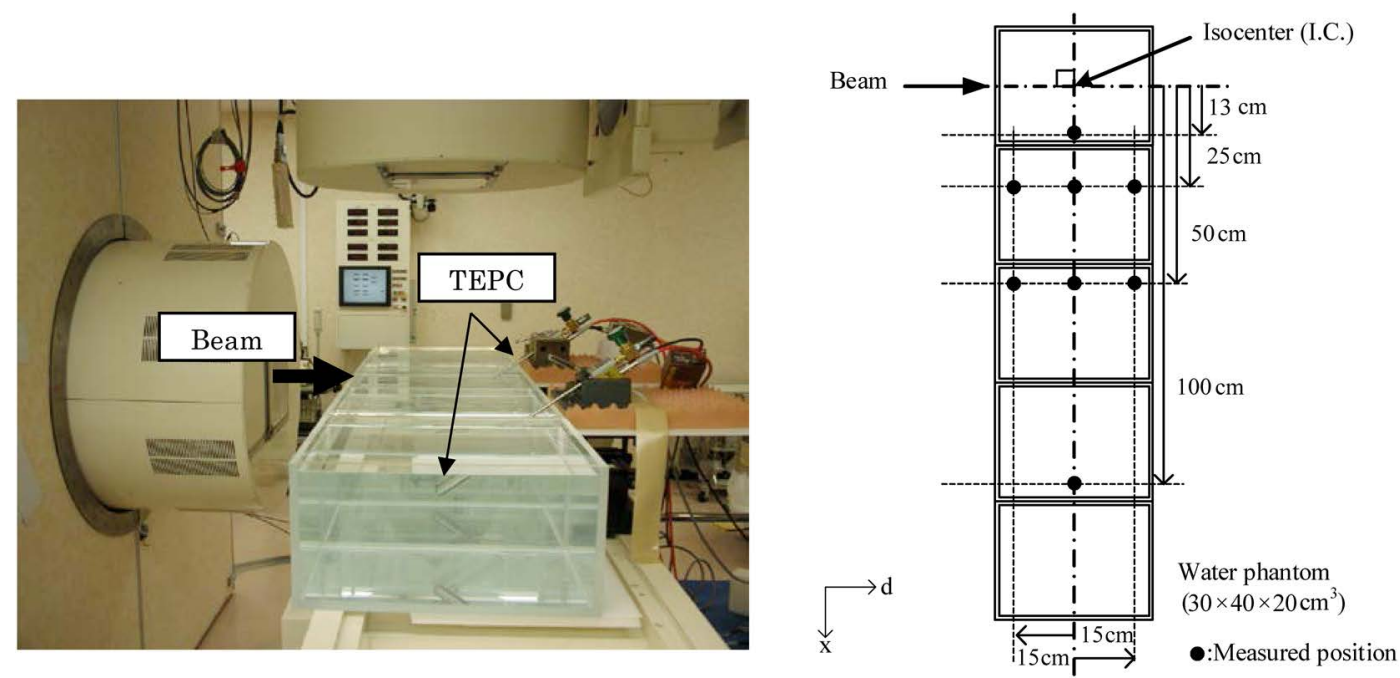

Fig. 4 Experimental setup. a) Photograph of the experimental setup in the HIMAC treatment room. b) Schematic view of the experimental setup (Color online). 


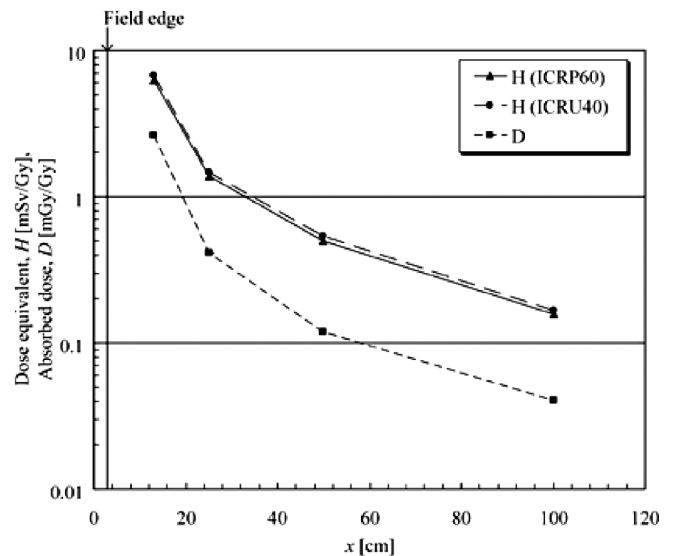

a)

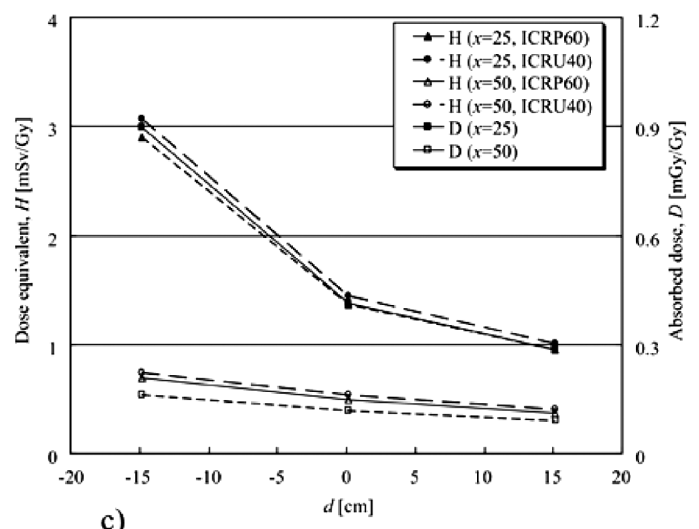

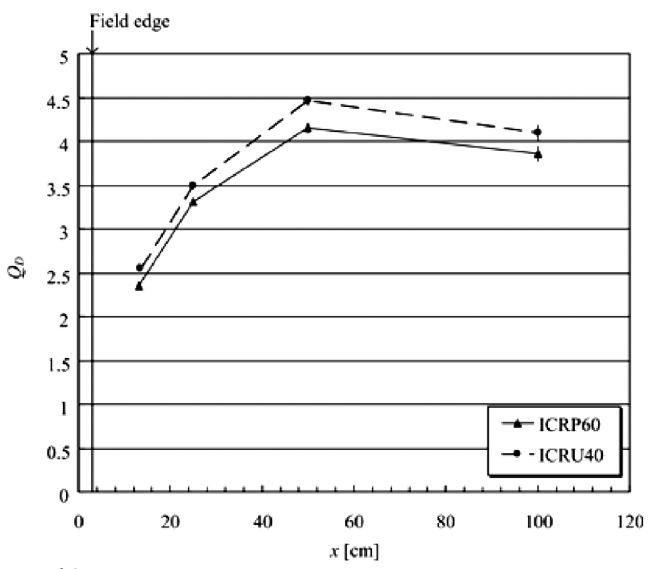

b)

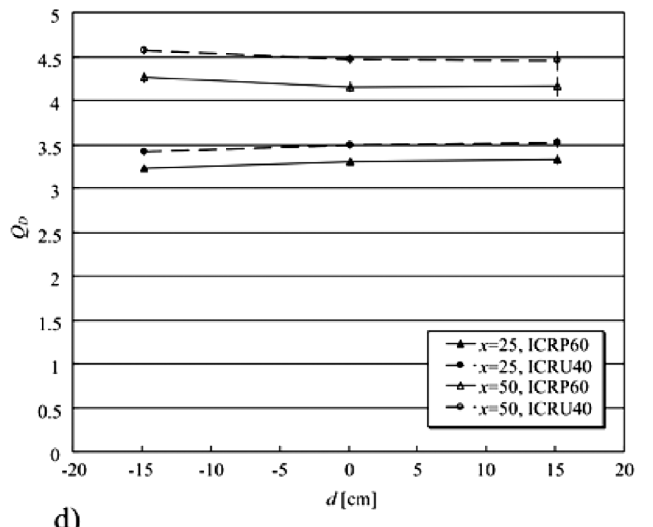

Fig. 5 Measured results for the $400 \mathrm{MeV} / \mathrm{u}$ carbon beam. The coordinate system is according to (x,d) shown in Fig. 4b) in which $(0,0)$ is defined at the isocenter. a) Absorbed dose and dose equivalents per the treatment absorbed dose at the center of the SOBP width at $\mathrm{d}=0$. b) Dose averaged quality factor at $\mathrm{d}=0$. c) Absorbed dose and dose equivalents per the treatment absorbed dose at the center of the SOBP width at $x=25$ or $50 \mathrm{~cm}$. d) Dose averaged quality factor at $\mathrm{x}=25$ or $50 \mathrm{~cm}$.

$2 \cdot 2$ 炭素線治療における照射野外の水ファン トム中吸収線量及び線質係数の测定 ${ }^{71}$

\section{$2 \cdot 2 \cdot 1$ 測定方法}

実験は, HIMAC 治療室 Bにおいて，290， $400 \mathrm{MeV} / \mathrm{u}$ 炭素ビームを用いて行った。ここで, 照射機器設定はSOBP 幅 $60 \mathrm{~mm}$, 照射野 $58.1 \times$ $50.0 \mathrm{~mm}^{2}$ とした。測定体系を Fig. 4 に示す。 5 台 の水ファントム $(40 \mathrm{~cm}$ (ビーム軸方向 $) \times 30 \mathrm{~cm} \times$ $20 \mathrm{~cm}$ (高さ)) を治療台に並べ，2台の組織等価 比例計数管 (TEPC, Far West 社製, 0.5 インチ $\varphi$, プロパンベースガス, サイトサイズ : $1 \mu \mathrm{m})$ を水 中に設置した。水ファントムの 1 台はその中心 がアイソセンターに一致するように設置し, 他
の4台はビーム軸に対して90方向に隣接して 設置した。測定位置はFig. 4 に示す 8 点であ る。 Lineal energy, yの広いダイナミックレンジ $(0.2-2000 \mathrm{keV} / \mu \mathrm{m})$ の測定を可能にするため, ア ンプゲインの異なる 3 台の主増幅器, 及び 3 台の MCA を用いて測定を行った。それぞれ入力で得 られた Lineal energy 分布, $\mathrm{f}(\mathrm{y})$ を基に, 吸収線 量 $\mathrm{D}$ は $\mathrm{y} \cdot \mathrm{f}(\mathrm{y})$ の積分により, また, 線質係数は ICRU40 に示されている Q $(\mathrm{y})$ 及び ICRP21,60に 示されている $\mathrm{Q}(\mathrm{L})$ (ここで, $\mathrm{L}=\mathrm{y}$ と仮定した)を 用いて算出した。また, 測定結果から, 線量平 均線質係数, $Q_{D}$, 線量当量, $H$ を算出した。 
Table 1 Estimated dose equivalents by assuming two opposed equally weighted irradiation for prostate cancer treatment in which the total prescribed dose of 66 Gy (RBE) was assumed. Here, values of the quality factor defined in ICRU 40 were used

\begin{tabular}{cc}
\hline \hline$(\mathrm{x}, \mathrm{d})$ & Dose equivalent, $H[\mathrm{mSv}]$ \\
\hline$(13,20)$ & 187 \\
\hline$(25,20)$ & 40.5 \\
\hline$(50,20)$ & 14.9 \\
\hline$(100,20)$ & 4.67 \\
\hline$(25,5)^{* *}$ & 57.0 \\
\hline$(50,5)^{* *}$ & 16.0 \\
\hline **: Two opposed equally wighted beams were assumed.
\end{tabular}

\section{$2 \cdot 2 \cdot 2$ 結果}

Fig. 5 に炭素線 $400 \mathrm{MeV} / \mathrm{u}$ に対する Q $, \mathrm{H}, \mathrm{D}$ の測定結果を示す。ここで, H 及び D は SOBP 中心の治療吸収線量当たりで規格化している。 ICRP60 と ICRU40の違いにより, QD 及び H は, 5-8\%の違いが現れる。 H, D は照射野及び ビーム入射面から離れると值が小さくなり， H は $6.7 \mathrm{mSv} / \mathrm{Gy}$ から $0.16 \mathrm{mSv} / \mathrm{Gy}$ であった。ま た， Q ないが，照射野に近づくほど值が小さくなっ た。これは，照射野により近いほど陽子などの 二次荷電粒子の線量寄与が大きいためと考えら れる。

\section{$2 \cdot 2 \cdot 3$ 考察及び結論}

Table 1 に対向 2 門による前立腺治療を仮定 し 66 Gy（RBE）の全線量を処方した場合の全線 量当量を示す。参考文献 8-10) に示されている 3D-CRT 及び IMRT の結果と比較すると, 炭素 線治療の線量当量は全ての点で同等もしくは低 い值であった。特に，照射野に近い位置におい ては, 明らかに低い值となり, 二次荷電粒子を 含めた照射野外線量においても相対的に二次が んリスクが3D-CRT や IMRT といった外部光子

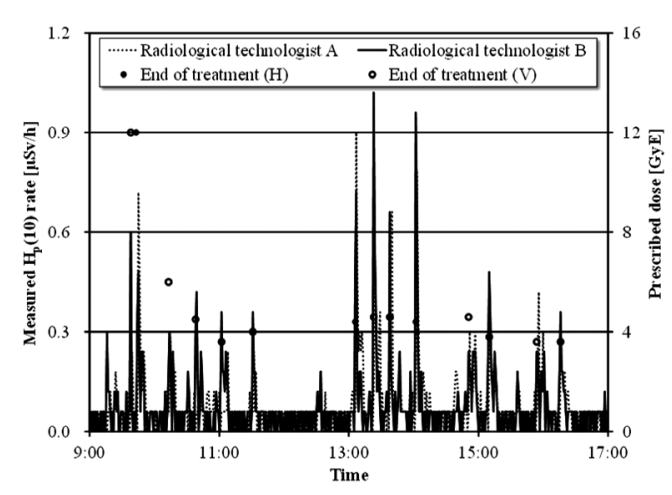

Fig. 6 Time course of the measured $\mathrm{H}_{\mathrm{p}}(10)$ rate on Day 1 . $(\mathrm{H})$ and $(\mathrm{V})$ are the horizontal and vertical irradiations, respectively.

線治療より低いことを示した。

\section{3. 照射野形成装置の放射化による医療従事者 の被ばく線量評価 ${ }^{11)}$}

高エネルギーX 線や粒子線を用いた放射線 治療では照射装置や患者内に放射性核種が誘発 される。これらの核種は潜在的に放射線従事者 の被ばくの原因となる。放射線従事者の中でも 診療放射線技師は照射室に頻繁にアクセスする ため, 光核反応を起こすような高エネルギー X 線治療における被ばく量評価の研究がいくつか 報告されている ${ }^{12,13)}$ 。本研究では, アクティ ブ型個人線量計を用いて, 放医研で治療に従事 する診療放射線技師の年間被ばく線量 (個人線 量当量 : $\left.\mathrm{H}_{\mathrm{p}}(10)\right)$ を推定した。

$3 \cdot 1 \cdot 1$ 測定方法

本研究では富士電機製高機能積算線量計 Dose e nano を用いた。この線量計はシリコン 半導体検出器であり, $\mathrm{H}_{\mathrm{p}}(10)$ を直接出力でき ること, 積算下限線量が $1 \mathrm{nSv}$ と極めて低いこ と, 1 分毎に積算線量をメモリーに保存可能で あることという特徵を持つ。被ばく線量の推定 においては, 放医研の HIMAC 棟（拡大ビーム 法) 及び新治療研究棟 (スキャニング法)に従 事するそれぞれ 2 人の放射線技師に 1 週間, 上 記の線量計を携帯させ, メモリーに保存された 線量変化を解析した。 


\section{$3 \cdot 1 \cdot 2$ 結果}

測定結果の 1 例として, Fig. 6 に測定 1 日目 における線量率の変化を治療照射終了時刻及び 処方線量と共に示す。線量率の変化から診療放 射線技師の被ばくは照射後の治療室内作業の短 い時間に限定されていることが明らかになっ た。ゆえに年間の被ばく線量は照射あたりの $\mathrm{H}_{\mathrm{p}}(10)$ と年間治療照射数で概算できると判断 した。治療照射あたりの平均及び最大 $\mathrm{H}_{\mathrm{p}}(10)$ は, HIMAC 棟で $0.019,0.023 \mu \mathrm{Sv}$, 新治療研究 棟で $0.001,0.004 \mu \mathrm{Sv}$ であった。これらの測定 值と 2013 年度の HIMAC 棟 B 室及び新治療研 究棟 F 室での照射回数それぞれ3206, 1802 回か ら, HIMAC 棟では最大でも $74 \mu \mathrm{Sv}$, 新治療研 究棟では最大でも $7 \mu \mathrm{Sv}$ であるという結果を得 た。新治療研究棟における治療照射は年々増 加しているものの, 2017 年度の E 室の実績 : 4439 照射を基にしても $\mathrm{H}_{\mathrm{p}}(10)$ は最大 $18 \mu \mathrm{Sv}$ と 見積もることができる。

\section{$3 \cdot 1 \cdot 3$ 考察及び結論}

炭素線治療に従事する診療放射線技師の誘導 放射能による年間被ばく線量を推定した。その 結果, ICRPで推奨される年間線量限度を大き く下回ることが明らかになった。また，高エネ ルギーX 線治療施設に従事する診療放射線技 師の放射化物から体幹部への吸収線量は年間 $0.7 \mathrm{mGy}$ と参考文献 12) で実験的に評価されて いる。本研究は $\mathrm{H}_{\mathrm{p}}(10)$ を直接測定しており評 価量が異なるが, 本研究で算出された炭素線治 療施設に従事する診療放射線技師の年間被ばく 線量は高エネルギーX 線治療施設に従事する 診療放射線技師の值より低いと推測される。

\section{4. 患者の放射化による介助者・介護者の被ば く線量評価 ${ }^{14)}$}

高エネルギーX 線や粒子線を用いた放射線 治療では患者内に放射性核種が誘発され，それ によって, 患者の介助者・介護者が被ばくする 可能性がある。患者の介助者・介護者の被ばく はICRP では医療被ばくの一つとされ，1事例

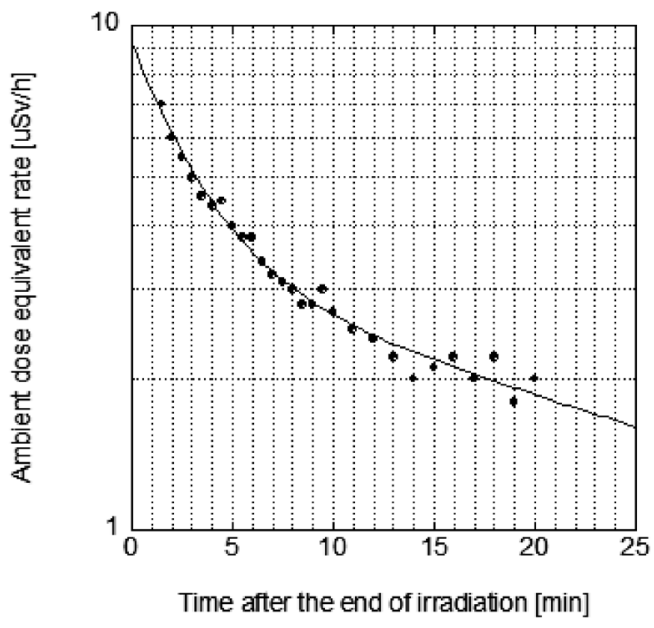

Fig. 7 Time course of measured ambient dose equivalent rate, $\dot{H}^{*}(10)$ at $300 \mathrm{~mm}$ from the surface of the irradiated phantom.

あたり $5 \mathrm{mSv}$ という線量拘束值が锥告されてい る。本研究では, 人体を模擬したファントムに 治療ビームを照射し，ファントム内に生成した 放射性核種からの線量率変化を測定すること で，患者の放射化による介助者・介護者の典型 的な被ばく線量を評価した。

$4 \cdot 1 \cdot 1$ 測定方法

実験は HIMAC 治療室において行った。患者 の放射化を評価するため, 人体を模擬する夕フ ウォーターファントムと呼ばれる, 厚さ $300 \mathrm{~mm}$ のブロックをアイソセンターに設置し, エネル ギー：400 MeV/u，照射野：100 mm×100 mm, SOBP 幅: $60 \mathrm{~mm}$ のビーム条件で, SOBP 中心 における吸収線量が $5 \mathrm{~Gy}$ となるよう照射した。 照射終了後, ファントムを治療ホールなど線量 率の低い場所に移動して, ファントム上流面か ら $300 \mathrm{~mm}$ (ファントム表面から検出器中心まで の距離) での周辺線量当量率, $\dot{H}^{*}(10)$ を電離箱 式サーベイメータで 30 秒ごとに測定した。介 助者・介護者の被ばく線量は, 照射終了 2 分後 に患者が照射室から出た後, 家族が 2 時間付き 添った場合の積算線量と仮定した。また, 炭素 線治療は通常分割照射が行われることを考虑 し, 30 回同様の被ばくを受けるとした。（放医 
研での炭素線治療では平均 12 回程度の分割で ある。)

\section{$4 \cdot 1 \cdot 2$ 結果}

Fig. 7 に周辺線量当量率, $\dot{H}^{*}(10)$ の測定結果 を示す。測定した線量率の時系列変化は，2 種 類の指数関数の和である次式で精度よくフィッ トすることができた。

$$
\dot{H}^{*}(10)(t)=5.95 e^{-t / 2.92}+3.32 e^{-t / 34.3}
$$

ここで, $\dot{H}^{*}(10)(t)$ : 時間 $t$ における周辺線量 当量率 $[\mu \mathrm{Sv} / \mathrm{h}], t$ : 時間 $[\mathrm{h}]$ である。この結果 から，患者の放射化による介助者・介護者の被 ばく線量は $23.5 \mu \mathrm{Sv}$ と算出された。

\section{$4 \cdot 1 \cdot 3$ 考察及び結論}

Fig. 7 からわかるように誘発された放射性核 種の半減期が短いため, 付き添う時間をさらに 長く仮定しても被ばく量はほとんど増加しない ことなどを考慮すると，介助者・介護者が患者 から受ける線量は，1事例あたり $5 \mathrm{mSv}$ という 介助者・介護者の線量拘束值や一般公衆の線量 限度である $1 \mathrm{mSv} /$ 年と比較して，十分低い值で あると評価された。このことから，炭素線治療 を受けた患者の退出基準について考慮する必要 はないと結論づけられる。

\section{5. まとめ}

本稿では炭素線治療施設の治療運用に係わる 放射線防護のために HIMAC を用いて行われた 実験的研究の結果について紹介した。患者の医 療被ばくについては，現在実施されている他の 放射線治療と比較することで相対的にリスクを 議論し, 炭素線治療の二次発がんリスクは他の 放射線治療と同等もしくは低いことを示すこと ができた。また，照射野形成装置や患者の放射 化に関する研究から職業被ばく, 公衆被ばく, 介助者・介護者の医療被ばくは現行の国内規制 基準を十分満足しており，炭素線治療施設にお ける防護が既存の規制で対応できていることを 示した。ここで紹介していないものの，水や空 気の放射化についても計算により評価してお
り，同様に既存の規制で対応できることを示し ている ${ }^{14)}$ これらの研究結果の多くは, ICRP publication 127 にも掲載され, 粒子線治療施設 の治療運用に係わる放射線防護に大きく貢献し たと考えられる。

\section{文献}

1) Yonai, S., Matsufuji, N., Kanai, T., Matsui, Y., et al., Comparison of measured and calculated in-air secondary neutrons in passive carbon-ion radiotherapy, Radiat. Meas., 45, 1369-1373 (2010)

2) Reginatto, M., The "Few-channel" Unfolding Programs in the UMG Package: MXDFC33, GRVFC33 and IQUFC33, UMG Package. Version 3.3, Release Date 1 March 2004

3) Yonai, S., Matsufuji, N., Kanai, T., Matsui, Y., et al., Measurement of neutron ambient dose equivalent in passive carbon-ion and proton radiotherapies, Med. Phys., 35, 4782-4792 (2008)

4) Olsher, R. H., Hsu, H. H., Beverding, A., Kleck, J. H., et al., WENDI: an improved neutron rem meter, Health Phys., 79, 170-181 (2000)

5) Yonai, S., Furukawa, T. and Inaniwa, T., Measurement of neutron ambient dose equivalent in carbonion radiotherapy with an active scanned delivery system, Radiat. Prot. Dosimetry, 161, 433-436 (2014)

6) Hall, E. J., Intensity-modulated radiation therapy, protons, and the risk of second cancers, Int. J. Radiat. Oncol. Biol. Phys., 65, 1-7 (2006)

7) Yonai, S., Kase, Y., Matsufuji, N., Kanai, T., et al., Measurement of absorbed dose, quality factor, and dose equivalent in water phantom outside of the irradiation field in passive carbon-ion and proton radiotherapies, Med. Phys., 37, 4046-4055 (2010)

8) Kry, S. F., Salehpour, M., Followill, D. S., Stovall, M., et al., The calculated risk of fatal secondary malignancies from intensity-modulated radiation therapy, Int. J. Radiat. Oncol. Biol. Phys., 62, 1195-1203 (2005)

9) Kry, S. F., Salehpour, M., Followill, D. S., Stovall, M., et al., Out-of-field photon and neutron dose equivalents from step-and-shoot intensity-modulated radiation therapy, Int. J. Radiat. Oncol. Biol. Phys., 62, 1204-1216 (2005)

10) Kry, S. F. S., Followill, D., White, R. A., Stovall, M., et al., Uncertainty of calculated risk estimates for secondary malignancies after radiotherapy, Int. J. Radiat. Oncol. Biol. Phys., 68, 1265-1271 (2007) 
11) Yonai, S. and Spano, V., Dose to radiological technologists from induced radionuclides in carbon ion radiotherapy, Radiat. Prot. Dosimetry, 170, 322-325 (2016)

12) Almén, A., Ahlgren, L. and Mattsson, S., Absorbed dose to technicians due to induced activity in linear accelerators for radiation therapy, Phys. Med. Biol., 36, 815-822 (1991)

13) Rawlinson, J. A., Islam, M. K. and Galbraith, D. M., Dose to radiation therapists from activation at high-energy accelerators used for conventional and intensity-modulated radiation therapy, Med. Phys., 29, 598-608 (2002)

14) Tujii, H., Akagi, T., Akahane, K., Uwamino, Y., et al., Research on radiation protection in the application of new technologies for proton and heavy ion radiotherapy, Jpn J Med Phys, 28, 172-206 (2009)

15) ICRP, Radiological Protection in Ion Beam Radiotherapy. ICRP Publication 127, Ann. ICRP, 43, (2014)

\section{Abstract}

Applications of Charged Particle Accelerators -Impact of the NIRS-HIMAC Facility-

Section 7 【Radiation Safety】 Radiation Safety of High-energy Particle-accelerator Facilities 7.2.6 Radiation Protection in Carbon-ion Radiotherapy
Shunsuke YONAI ${ }^{\dagger}$ : Department of Accelerator and Medical Physics, National Institute of Radiological Sciences, National Institutes for Quantum and Radiological Science and Technology, 4-9-1 Anagawa, Inage-ku, Chiba 263-8555, Japan, ${ }^{\dagger}$ yonai.shunsuke@qst.go.jp

Experimental researches on radiation protection in carbon ion radiotherapy were performed in the HIMAC treatment rooms. Some of the key results on dose assessments for medical exposure of patients, medical exposure of careers and comforters, and occupational exposure were introduced here. The undesired exposure to normal tissues outside the treatment volume was investigated by measurements with a portable neutron rem-meter and a tissue equivalent proportional counter. These results indicated that the secondary cancer risk after carbon ion radiotherapy are comparable or less than other external radiation therapy modalities. The doses to radiation technologists working in the carbon ion radiotherapy facility and careers and comforters of the patients from radioactive irradiation devices and patients induced by therapeutic carbon beam were estimated based on experimental measurements. These results demonstrated that the carbon ion radiotherapy facility can be safely operated by current Japanese regulations according to the ICRP recommendations. A lot of these results have been cited in the ICRP publication 127: Radiological protection in ion beam radiotherapy. We therefore believe that these researches offered a significant contribution toward the promotion of carbon ion radiotherapy. 